\title{
Genotypic differences of storage proteins in four Scandinavian spring wheat cultivars during seed development
}

\author{
Jari Peltonen and TuUla Sontag-Strohm
}

\begin{abstract}
Peltonen, J. \& Sontag-Strohm, T. 1992. Genotypic differences of storage proteins in four Scandinavian spring wheat cultivars during seed development. Agric. Sci. Finl. 1: 499-507. (Univ. Helsinki, Dept. Plant Production, Viikki, SF-00710 Helsinki, Finland and Univ. Helsinki, Dept. Food Technology, Viikki, SF-00710 Helsinki, Finland.)
\end{abstract}

\begin{abstract}
Wheat (Triticum aestivum L.) is grown under a wide range of climatic conditions. Therefore, it is necessary to understand the underlying physiological phenomena which affect the quality of grain yield. The aim of this project was to study the interactions between cultivars in their accumulation and relative concentrations of the different protein groups of storage proteins at various stages of wheat grain development. Yield components, protein quantity and the quality of flour were examined. The study was carried out at the University of Helsinki, Department of Plant Production during 1989-1990. The cultivars used were Heta, Ruso, Reno and Kadett. In northern latitudes the early maturity class of a genotype is an important selection criterion associated with good breadmaking quality. The short grain filling period leads to a high rate of accumulation of high molecular weight glutenins, because it coincides with a rapid expansion of the endosperm in the middle of grain filling. The associated yield loss in these cultivars may be compensated by higher number of grains per ear. Therefore, selection of productive wheat lines with early maturity, high protein concentration and high relative amount of high molecular weight glutenins, and high grain number per ear instead of high kernel weight may lead to more stable yield and improved breadmaking quality.
\end{abstract}

Key words: wheat, Triticum aestivum L., storage proteins, yield components, northern latitudes

\section{Introduction}

The main problem in many regions of wheat cultivation is to produce a good yield each year with sufficient protein concentration needed for breadmaking. As early as the 1930-1940s it was observed that the breadmaking quality of wheat was not dependent only on the protein concentration of grains but also on the quality of protein (HUTTUNEN 1938, FinNeY and BARMORE 1948). PugAR and SASEK (1970) reviewed the findings of several researchers according to which an increase in the grain protein concentration consistently led to a great increase in the gliadins, a smaller increase in the glutenin, and a slight increase in the albumins and globulins. Doekes and WenNEKES (1982) showed that with increasing protein content only the gliadin content increased with increasing loaf volume; the glutenin, albumin and globulin contents did not change. According to SALOMONSSON and LARSSON-RAZNIKIEWICZ (1985), both the gliadins and the residue protein (insoluble in acetic 
acid) showed positive correlation with the grain protein concentration; the albumin and globulin contents were rather constant. These results contrast with observations of TANAKA and BUSHUK (1972) who indicated that all protein fractions vary in proportion to the total protein content of the flour, with no net change in the composition of protein. The contradictory reports are probably due to the differences between the fractionation method based on the solubility of the protein used and the different quantities of protein found. Recently, SHEWRY et al. (1986) reported that the classification of storage proteins based rather on their biological and functional properties than on their solubility characters. This classification groups storage proteins into high molecular weight glutenin (HMWG) subunits, S-poor prolamins, and S-rich prolamins.

Scandinavian wheat breeders have, for many years, selected bread wheat cultivars with a strong gluten by using the Zeleny sedimentation test, mixograph, test baking and other testing procedures (KIVI 1969, SvenSSON 1987, 1989, JuUTI 1988). Unfortunately, the amount of seed material needed for quality evaluation is usually not available in the early generations of a breeding program. Therefore, especially during the last decade, a great deal of interest has been shown towards the work of PAYNE et al. (1979, 1980, 1981 and 1987). They have shown by SDS-PAGE electrophoresis that the high molecular weight glutenin (HMWG) subunit composition of glutenin has a strong influence on the rheological and breadmaking properties of bread wheats, although HMWG comprises only some $10 \%$ of storage proteins in grain. In addition, Sozinov and Poperelya (1984) indicated the importance of different gliadin patterns to breadmaking quality. In all of the previous work in Scandinavia (SONTAG and SAlovaARA 1985, SonTAG et al. 1986, MosLeth and UhLEN 1990, UhLEN 1990a,b) which examined the effects of cultivars on the protein quality of the wheat, only the mature grain has been studied. The aim of the present study was to further characterise the physiological changes affecting protein quality in wheat grains in addition to grain yield formation. This was achiev- ed by following the changes in protein quality as a function of the developmental stage of grain filling, and by studying the yield components of cultivars.

\section{Material and methods}

The field trials were carried out at the Experimental Farm of the University of Helsinki (Viikki) and at Hankkija Plant Breeding Institute (Anttila). The study period covered the growing seasons of 1989 and 1990. Spring wheat (Triticum aestivum L.) cultivars Heta, Ruso (Finnish origin), Reno (Norwegian), and Kadett (Swedish) were grown in plots of $10 \mathrm{~m}^{2}$ at Viikki and $8 \mathrm{~m}^{2}$ at Anttila. A completely randomized block design with four replications was used in both locations and in both years. Plots were fertilized at the recommended rate of $110 \mathrm{~kg}$ $\mathrm{N}$ ha ${ }^{-1}$.

The grain filling periods studied were those initiated after pollination. Pollination was observed using the micro-morphological scale of WADDINGTON et al. (1983). The developmental stage was determined from fifteen stems per cultivar and was considered to have been attained when at least $60 \%$ of the plants were at the particular stage. Fifty spring wheat ears were collected 10,17, 24, 31 days after pollination (DAP), and the last ear samples were collected at full maturity (42-49 DAP).

The collected ear samples were threshed by hand. The grain samples were finely milled in a Udy cyclone sample mill (Udy Corp., Boulder, CO, U.S.A.) equipped with a $0.5-\mathrm{mm}$ sieve. The analysis of storage proteins was carried out by SDSPAGE using $15.0 \%$ acrylamide gels at $\mathrm{pH} 8.8$ according to RAHMAN et al. (1987). Relative amounts of the different protein groups were determined by densitometry using an LKB 2222-020 UltroScan XL Laser Densitometer (Model 2222020, Pharmacia LKB Biotechnology, Sweden). Each lane was scanned twice, using different tracks of a duplicate gel. The proteins were classified into high molecular weight glutenins HMWG (m.w. 136 - $67.5 \mathrm{kDa}$ ), S-poor prolamins SPP (m.w. 67.5 - $51.5 \mathrm{kDa}$, mainly omega-gliadins), and S-rich prolamins SRP (m.w. 51.5 - $32.0 \mathrm{kDa}$, mainly low 
molecular weight glutenins, alpha-, beta- and gamma-gliadins) according to SHEWRY et al. (1986). A typical trace of SDS-PAGE and corresponding densitometric readings are shown in Figure 1. The HMWG subunit composition of the wheat cultivars was determined by using $10 \%$ gel. Glu-1 scores were determined according to PAYNE et al. (1987). Gliadins were separated by A-PAGE (BUSHUK and ZiLlman 1978).

Grain yield per ear, number of grains per ear and kernel weight were determined from 30 plants per plot in each of the four replications. The grain yield per plot was expressed in grams per square meter. The duration of grain filling phase was determined as the number of days from pollination to maturity. The mean grain filling rate per day and per ear were calculated from grain yield per ear divided by the duration of grain filling in days. The replicated yield samples were pooled and mixed thoroughly for quality analyses. Subsamples $(2 \mathrm{~kg})$ at a moisture concentration of $15 \%$ were milled with a Brabender Quadrumat Senior Mill (Model Q.U.-S.,
Duisburg, Germany). Following storage of the samples at room temperature for two weeks, the protein concentration of the flour (AACC 1983) and the gluten content (ICC 1982) were determined. Protein quality was assessed by Zeleny sedimentation volume (AACC 1983), and farinograph doughs developmental time and mixing stability by the standard of ICC (1972).

The data was subjected to ANOVA for significances of differences and regression analysis with the MSTAT statistical package.

\section{Results and discussion}

The HMWG subunit compositions were $1,7+9$, and $5+10$ in cultivars Ruso, Reno and Kadett, and $2^{*}, 6+8$, and $5+10$ in cultivar Heta (data not shown). The HMWG subunit quality scores according to PAYNe et al. (1987) were 9 for Ruso, Reno, and Kadett, and 8 for Heta. The examined cultivars displayed more variation in both SPP and SRP compositions in A-PAGE (Fig. 2). Previously

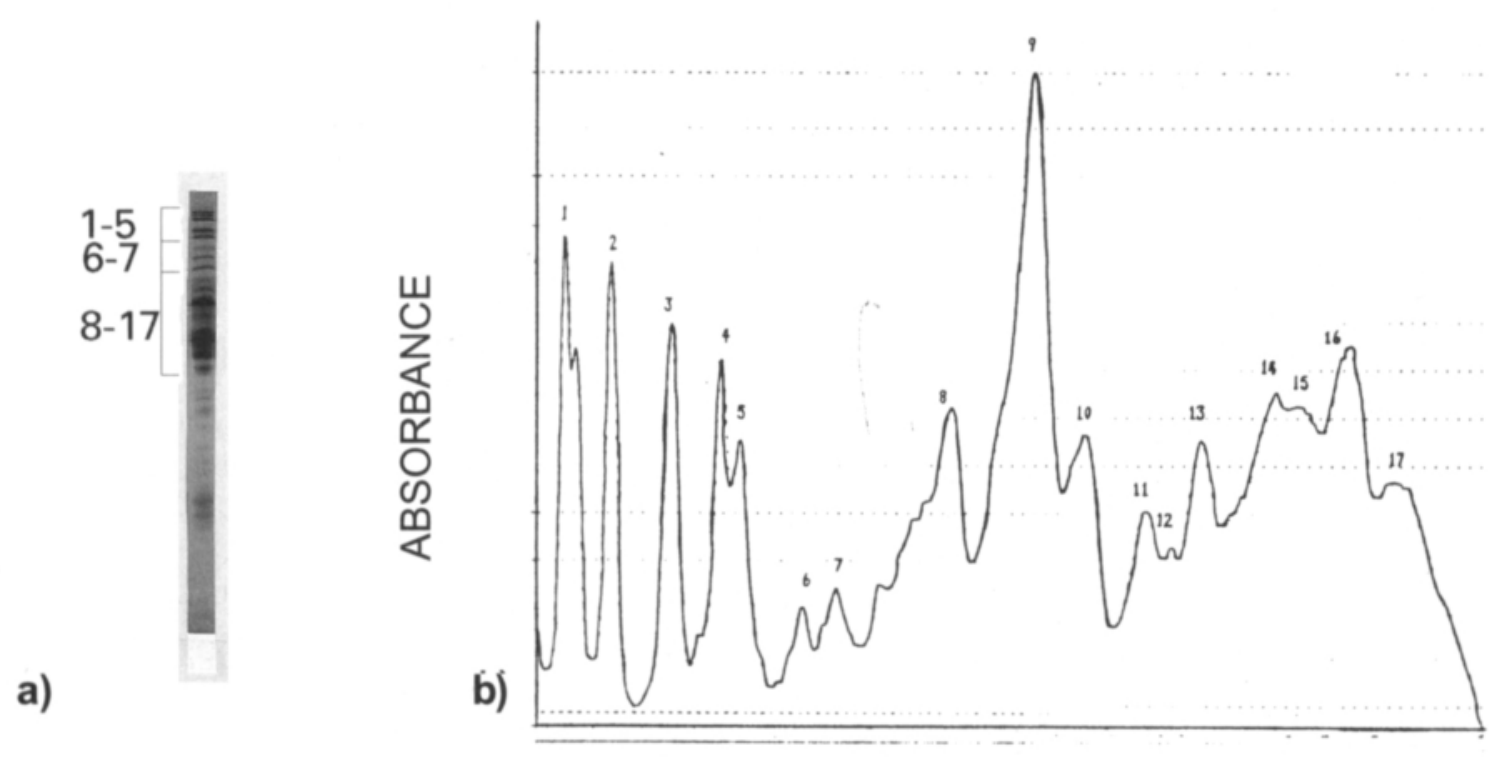

Fig. 1. a) SDS-PAGE and b) densitometric readings of total prolamin fractions from spring wheat (Cv. Heta). Within brackets HMWG subunits (1-5), S-poor prolamins (6-7), and S-rich prolamins (8-17). 


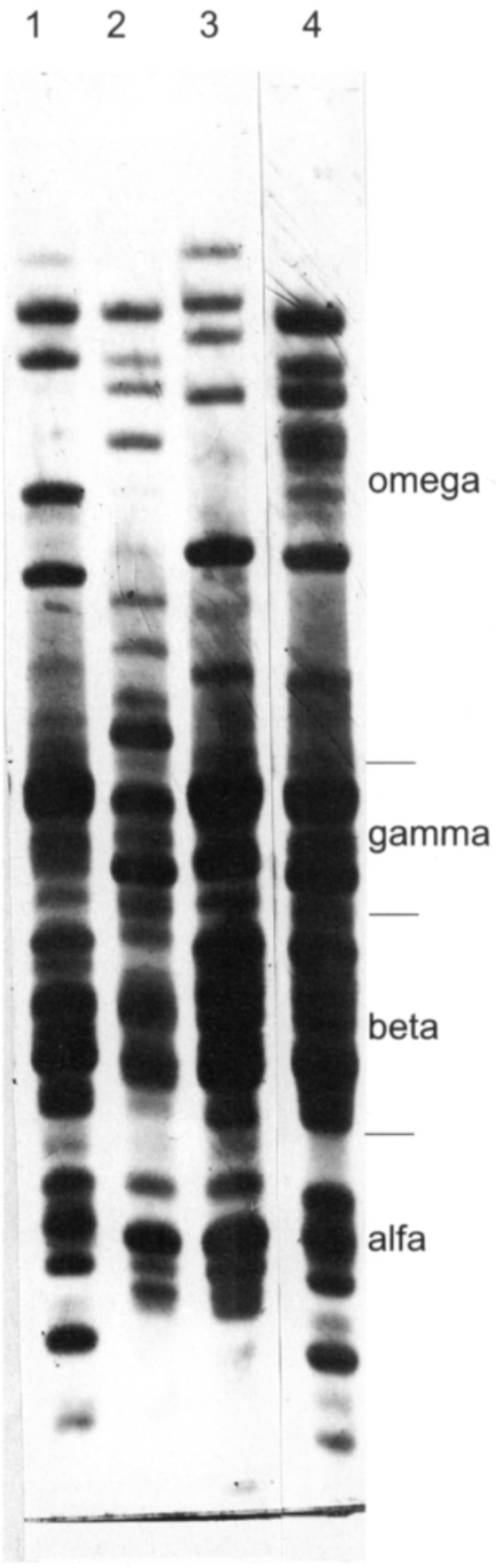

Fig. 2. The gliadin composition $(\mathrm{S}$-poor prolamins = omega gliadins, S-rich prolamins = gamma, beta, and alfa gliadins) of cultivars Ruso (1); Reno (2); Kadett (3), and Heta (4) in A-PAGE.
PAYNe et al. (1987), KHAN et al. (1989), and KRUGER and MARCHYLO (1990) showed that there is a positive correlation between HMWG subunits and breadmaking quality. The amount of HMWG fraction also appears to be positively related to breadmaking quality (HAMADA et al. 1982, UHLEN 1990), which is confirmed by the results presented here (Table 1). According to a recent study by MOSLETH and UHLEN (1990), some omega-gliadin bands and some gamma-gliadin bands were either positively or negatively associated with flour quality. Qualitative analysis of storage proteins indicated that although the HMWG subunit compositions and quality scores were the same in Ruso, Reno, and Kadett, the synthesis and kinetics of HMWG differed significantly between these genotypes (Fig. 3). Therefore, synthesis and accumulation of the HMWG component is obviously requlated by genes which are associated with the quantity of grain protein concentration (LAW and PAYNE 1983). Our results show that SPP and SRP had either a positive or a negative effect on baking quality (Table 1). Sozinov and Poperelya (1984) have shown how different allelic variants of gliadin were related to breadmaking quality.

The duration of the grain filling phase in the cultivars studied varied from 42 to 49 days (Fig. 3, Table 2). Accordingly, the shorter the duration of the grain filling period, the more the synthesis of HMWG was parabolic, reaching its maximum in the middle of the grain filling phase (about 24 DAP), after which its proportion levelled off (Fig. 3). This was particularly the case with Heta; in Ruso the parabolic shape was less pronounced. The synthesis of HMWG in Reno was stable until 31 DAP, and thereafter the relative content of HMWG was proportionately reduced towards maturity, while the content of HMWG in Kadett showed a trend of linear decrease from 10 DAP to maturity (Fig. 3). The accumulation of SRP seemed to be reduced at an early stage of the grain filling period (10 DAP) in the late maturing Reno and Kadett compared to Heta and Ruso. The proportion of HMWG as opposed to SPP was higher in Kadett than the other cultivars at all stages of grain filling 
Table 1. Correlation coefficients of high molecular weight (HMWG) glutenins, S-poor prolamins (SPP) and S-rich prolamins (SRP) in protein and bread quality characteristics.

\section{Cultivar}

\begin{tabular}{|c|c|c|c|c|c|c|c|c|c|c|c|c|}
\hline Correlation with & $\begin{array}{l}\text { Heta } \\
\text { HMWG }\end{array}$ & SPP & SRP & $\begin{array}{l}\text { Ruso } \\
\text { HMWG }\end{array}$ & SPP & SRP & $\begin{array}{l}\text { Reno } \\
\text { HMWG }\end{array}$ & SPP & SRP & $\begin{array}{l}\text { Kadett } \\
\text { HMWG }\end{array}$ & SPP & SRP \\
\hline $\begin{array}{l}\text { Flour protein } \\
\text { concentration }\end{array}$ & $0.48^{* *}$ & $-0.52^{* * *}$ & - & $0.42^{* *}$ & $-0.39^{*}$ & - & $0.52^{* * *}$ & - & $-0.59 * * *$ & - & - & - \\
\hline Gluten content & $0.48^{* *}$ & $-0.42^{* *}$ & - & - & $-0.46^{* *}$ & - & $0.47^{* *}$ & $0.35^{*}$ & $-0.59 * * *$ & - & - & - \\
\hline $\begin{array}{l}\text { Zeleny } \\
\text { sedimentation }\end{array}$ & $0.60^{* * *}$ & $-0.45^{* *}$ & - & $0.54^{* * *}$ & $-0.35^{*}$ & - & $0.49 * *$ & $0.35^{*}$ & $-0.59 * * *$ & $0.48^{* *}$ & - & $0.33^{*}$ \\
\hline $\begin{array}{l}\text { Dough } \\
\text { development time }\end{array}$ & $0.46^{* *}$ & $-0.62 * * *$ & - & $0.36^{*}$ & $-0.44^{* *}$ & - & $0.57^{* * *}$ & - & $-0.46^{* *}$ & $0.37^{*}$ & - & - \\
\hline Mixing stability & $0.46^{* *}$ & $-0.43^{* *}$ & - & - & $-0.37^{*}$ & - & $0.46^{* *}$ & - & $-0.40^{*}$ & - & $-0.36^{*}$ & - \\
\hline
\end{tabular}

$*{ }^{* *},{ }^{* * *}=$ significant at $\mathrm{P}=0.05,0.01,0.001$, respectively

Heta

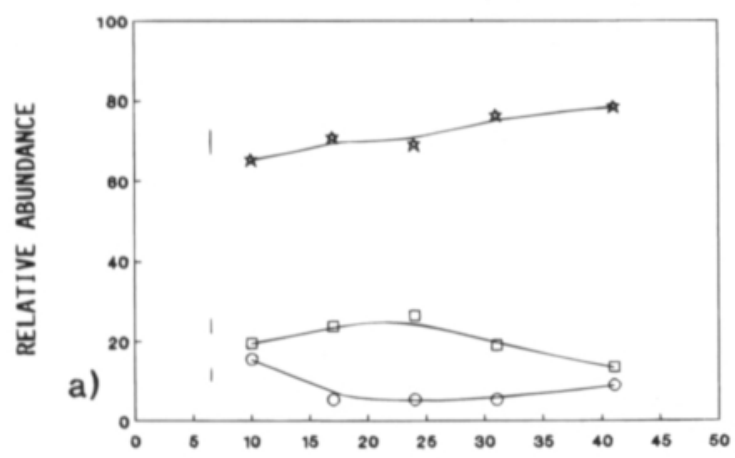

Reno

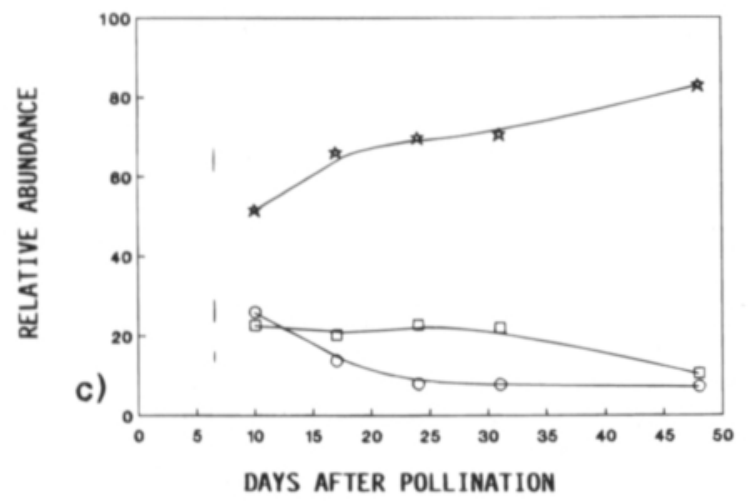

Ruso

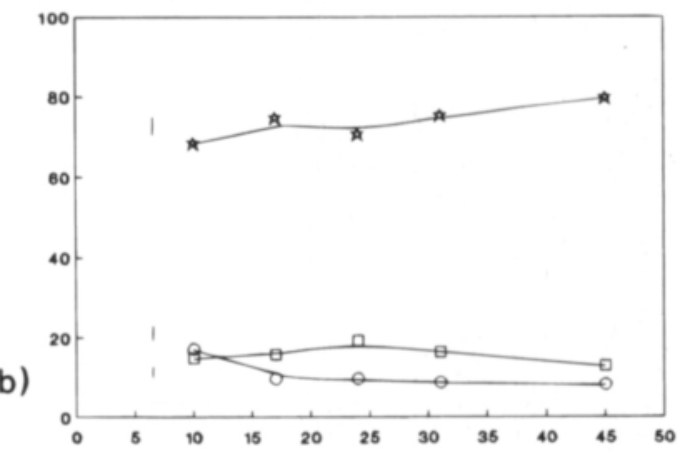

Kadett

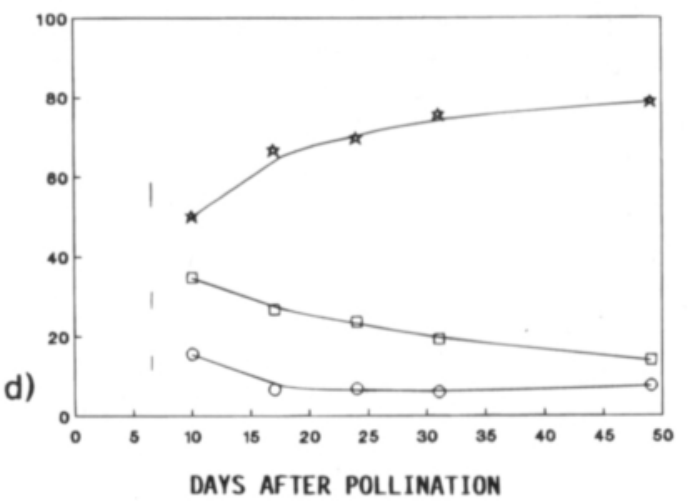

Fig. 3. Relative abundance of high molecular weight glutenins (HMWG), S-poor prolamins (SPP), and S-rich prolamins (SRP) during grain filling phase of cultivars Heta (a), Ruso (b), Reno (c), and Kadett (d). - - - HMWG, - o - SPP, and - * SRP. Vertical lines indicate LSD at $\mathrm{P}=0.05$ probability level. 
until maturity. These results suggest that the accumulation and kinetics of SPP and SRP is affected by many allelic variants (cf. Fig. 2 and Fig. 3). Both the parabolic and the linearly decreasing patterns of HMWG synthesis may lead to a high proportion of HMWG in mature grains (cf. Heta and Kadett; Fig. 3 , Table 2). However, only the parabolic pattern of HMWG synthesis in Heta seemed to lead to high flour protein concentration and high protein quality measured as Zeleny sedimentation volume, dough development time and mixing stability.

The high rate of HMWG accumulation in the middle of the grain filling period was associated with the low yielding ability of cultivar Heta (Fig. 3 and Table 2). The poor grain yield of this cultivar was related to low kernel weight, low number of grains per ear, and short grain filling period as a consequence of low efficiency in grain filling rate per day. The reason for this may be that when the rapid expansion of the endosperm occurred (BRIARTY et al. 1979), the synthesis of HMWG consumed more energy, consequently reducing the resources available for carbon assimilation (Fig. 3, Heta). This hypothesis is confirmed by the results of Mrtra et al. (1979) which showed that the accumulation of glutenins requires more energy than that of gliadins. In addition, PENNING de VRIES et al. (1974) estimated that 1 gram of glucose produced by photosynthesis can be used by the crop to produce either 0.40 of protein or 0.83 of carbohydrates.

The reduced rate of accumulation of HMWG in the middle of the grain filling period, may be a characteristic of poor quality cultivars. The flour protein concentration was similar in Ruso, Reno and Kadett (Table 2), but their accumulation curves of HMWG were totally different (Fig. 3). The probable reason for the observed decrease in protein content was the high grain yields of Ruso, Reno and Kadett. Grain yields of Ruso and Kadett were associated with a high kernel weight. A high grain filling rate was also observed in Ruso and a prolonged duration of the post-anthesis phase in Kadett. In Reno the most prominent yield component was the high number of grains per ear. The calculations based on protein concentration and grain yield per ear (Table 2) showed that the amount of protein per ear was $94.3 \mathrm{mg}$ in Heta, $93.2 \mathrm{mg}$ in Reno, $88.7 \mathrm{mg}$

Table 2. Pooled data of yield components and bread quality characters of wheat cultivars.

\begin{tabular}{|c|c|c|c|c|c|c|c|}
\hline \multirow[b]{3}{*}{ Duration of grain filling (day) } & \multicolumn{6}{|c|}{ Cultivar } & \multirow{3}{*}{$\begin{array}{l}\text { prob. } \\
\mathrm{P}<0.05\end{array}$} \\
\hline & \multicolumn{2}{|c|}{ Heta } & \multicolumn{2}{|c|}{ Ruso } & Reno & Kadett & \\
\hline & 42 & $(3.93)^{z}$ & 45 & $(6.29)$ & $47 \quad(6.59)$ & $49 \quad(6.17)$ & \\
\hline Mean grain filling rate $\mathrm{ear}^{-1}(\mathrm{mg} /$ day $)$ & 18.5 & $(1.70)$ & 19.3 & $(1.27)$ & $18.9(1.26)$ & $17.2(1.43)$ & $\mathrm{P}<0.001$ \\
\hline Grain yield ear ${ }^{-1}(\mathrm{mg})$ & 779.0 & $(150)$ & 869.4 & $(120)$ & $887.8 \quad(150)$ & $841.8 \quad(160)$ & $\mathrm{P}<0.001$ \\
\hline Kernel weight (mg) & 34.0 & $(2.60)$ & 39.1 & $(2.80)$ & $33.5 \quad(2.26)$ & $37.6 \quad(3.26)$ & $\mathrm{P}<0.001$ \\
\hline Grain number ear ${ }^{-1}$ & 22.9 & $(3.47)$ & 22.2 & $(2.47)$ & $25.2 \quad(3.82)$ & $22.3 \quad(3.25)$ & $\mathrm{P}<0.001$ \\
\hline Grain yield $\mathrm{m}^{-2}(\mathrm{~g})$ & 430.2 & $(60.70)$ & 486.8 & $(47.34)$ & $486.0(49.52)$ & $486.5(50.87)$ & $\mathrm{P}<0.001$ \\
\hline Flour protein concentration $\left(\mathrm{g} \mathrm{kg}^{-1}\right)$ & 12.1 & $(1.47)$ & 10.2 & $(1.22)$ & $10.5 \quad(1.37)$ & $10.5 \quad(1.34)$ & $\mathrm{P}<0.001$ \\
\hline Gluten content $(\%)$ & 35.1 & $(5.76)$ & 28.3 & $(4.50)$ & $29.1 \quad(4.12)$ & $28.6 \quad(3.93)$ & $\mathrm{P}<0.001$ \\
\hline Zeleny sedimentation (ml) & 42.6 & $(11.02)$ & 32.1 & (4.49) & $34.9(4.08)$ & $39.9 \quad(4.65)$ & $\mathrm{P}<0.001$ \\
\hline Dough development time (min) & 4.3 & $(1.87)$ & 3.1 & (1.27) & $2.8(0.96)$ & $2.8 \quad(1.01)$ & $\mathrm{P}<0.001$ \\
\hline Mixing stability (min) & 6.0 & $(2.48)$ & 4.0 & (1.98) & $4.8 \quad(1.45)$ & $4.6 \quad(2.26)$ & $\mathrm{P}<0.001$ \\
\hline \multicolumn{8}{|l|}{ Relative abundance (\%) } \\
\hline - HMW glutenins (HMWG) & 13.5 & $(3.19)$ & 12.7 & (3.28) & $10.5 \quad(2.62)$ & $13.9 \quad(2.64)$ & $\mathrm{P}<0.001$ \\
\hline - S-poor prolamins (SPP) & 8.9 & $(2.93)$ & 8.0 & (3.16) & $7.1 \quad(2.38)$ & $7.4 \quad(1.57)$ & $\mathrm{P}<0.05$ \\
\hline - S-rich prolamins (SRP) & 78.4 & $(3.82)$ & 79.6 & $(4.30)$ & $82.7 \quad(4.30)$ & $78.8 \quad(3.04)$ & $\mathrm{P}<0.001$ \\
\hline
\end{tabular}

\footnotetext{
${ }^{\mathrm{z}}$ Standard deviations are in parentheses.
} 
in Ruso and $88.4 \mathrm{mg}$ in Kadett. Therefore, we suggest that the associated yield loss in high protein cultivars (e.g. Heta) would be compensated by a higher number of grains per ear (e.g. Reno). Selection of productive wheat lines with early maturity and high grain number per ear instead of high kernel weight may lead to more stable yield and improved breadmaking quality.

\section{Conclusions}

It is concluded that in northern latitudes the early maturity class is an important selection criterion for breadmaking quality. This is because the high rate of HMWG accumulation coincides with the rapid expansion of the endosperm in the middle of the short grain filling period. A high content of HMWG is clearly positively correlated with breadmaking quality, while no clear relationship was observed between the pattern of SPP and SRP synthesis, and breadmaking quality. However, based on our data it seems to be questionable, whether the high values of HMW glutenin subunit numbering systems are always related to high breadmaking quality. Our results suggest that selection for breadmaking quality according to electrophoretic patterns of HMW glutenin subunits should also be made on a quantitative basis. The selection of wheat lines with an early maturity and high grain number per ear instead of high kernel weight, together with a high proportion of HMWG and high protein concentration are the most important parameters to go for in a breeding program.

Acknowledgements. The authors are grateful Dr. Eija Pehu for her constructive criticism of the manuscript. The excellent technical assistance of Mr. Antti Korpinen and Mr. Kari Kammiovirta is gratefully acknowledged.

\section{References}

AACC 1983. Approved methods of the AACC, Vol. I, II. 8th ed. Methods 46-11, 56-61. American Association of Cereal Chemists, Inc., St. Paul, Minnesota, U.S.A.

Briarty, L.G., Hughes, C.E. \& Evers, A.D. 1979. The developing endosperm of wheat - A stereological analysis. Ann. Bot. 44: 641-658.

BuSHUK, W. \& ZILLMAN, R.R. 1978. Wheat cultivar identification by gliadin electrophoregrams. I. Apparatus, method and nomenclature. Can. J. Plant Sci. 58: 505-515,

DOEKES, G.J. \& WENNEKES, L.M.J. 1982. Effect of nitrogen fertilization on quantity and composition of wheat flour protein. Cereal Chem. 59: 276-278.

FINNEY, K.F. \& BARMORE, M.A. 1948. Loaf volume and protein content of hard winter and spring wheats. Cereal Chem. 25: 291-312.

Hamada, A.S., McDonald, C.E. \& SibBitt, L.D. 1982. Relationship of protein fractions of spring wheat flour to baking quality. Cereal Chem. 59: 296-301.

HUTTUNEN, E. 1938. Kasvinjalostus ja vehnăn leivonta-arvo. Hankkijan kasvinjalostuslaitos. Siemenjulkaisu 1938. p. 121-131.

ICC 1972. ICC-standard No. 115. Method for using the Brabender farinograph. International Association for Cereal Chemistry, Vienna. Verlag Moritz Schäfer, Detmold.

ICC 1982. ICC-standard No. 137. Mechanical determination of the wet gluten content of wheat flour (Glutomatic). International Association for Cereal Chemistry, Vienna. Verlag Moritz Schäfer, Detmold.

JuUTI, T. 1988. Targets in the breeding of spring wheat. J. Agric. Sci. Finl. 60: 281-291.

Khan, K., Tamminga, G. \& Lukow, O. 1989. The effect of wheat flour proteins on mixing and baking-correlations with protein fractions and high molecular weight glutenin subunit composition by gel electrophoresis. Cereal Chem. 66: 391-396.

Kıvı, E.I. 1969. Sadon käyttöarvo kevätvehnänjalostuksen tavoitteena. Quality properties in the Finnish spring wheat breeding. Ann. Agric. Fenn. 8: 193-204.

Kruger, J.E. \& MARChYLO, B.A. 1990. Analysis by reversed-phase high-performance liquid chromatography of changes in high molecural weight subunit composition of wheat storage proteins during germination. Cereal Chem. 67: 141-147.

LAw, C.N. \& PAYNE, P.I. 1983. Genetical aspects of breeding for improved grain protein content and type in wheat. J. Cer. Sci. 1: 79-93.

Mitra, R.K., BhatiA, C.R. \& RaBson, R. 1979. Bioenergetic cost of altering the amino acid composition of cereal grains. Cereal Chem. 56: 249-252.

Mosleth, E. \& Uhlen, A.K. 1990. Identification of qualityrelated gliadins and prediction of bread-making quality 
of wheat from the electrophoretic patterns of gliadins and high molecular weight subunits of glutenin. Nor. J. Agric. Sci. 4: 27-45.

PAyne, P.I. \& LAwrence, G.J. 1983. Catalogue of alleles for the complex gene loci, Glu-A1, Glu-B1, Glu-D1 which code for high-molecular-weight subunits of glutenin in hexaploid wheat. Cer. Res. Commun. 11: 29-35.

-, Corfield, K.G. \& Blackman, J.A. 1979. Identification of a high-molecular-weight subunits of glutenin whose presence correlates with bread-making quality in wheats of related pedigree. Theor. Appl. Genet. 55: 153-159.

—, LAw, C.N. \& MudD, E.E. 1980. Control by homoeologous group 1 chromosomes of the high-molecularweight subunits of glutenin, a major protein of wheat endosperm. Theor. Appl. Genet. 58: 113-120.

-, Holt, L.M. \& LAw, C.N. 1981. Structural and genetical studies on the high-molecular-weight subunits of wheat glutenin. Part 1; Allelic variation in subunits amongst varities of wheat (Triticum aestivum). Theor. Appl. Genet. 60: 229-236.

-, Nightingale, M.A., Krattiger, A.F. \& Holt, L.M. 1987. The relationship between HMW glutenin subunit composition and the bread-making quality of Britishgrown wheat varieties. J. Sci. Food Agric. 40: 51-65.

PenNing de VRIES, F.W.T., BrunstTIng, A.H.M. \& VAnLAar, H.H. 1974. Products, requirements and efficiency of biosynthesis: a quantitative approach. J. Theor. Bol. 45: 339-377.

Prugar, J. \& SASEK, A. 1970. Einfluss der Organischen und Mineraldüngung auf die Vertretung der Eiweissfraktionen im Weizenkorn. Getreide Mehl 20(4): 27-29.

RAHMAN, S., SHEWRY, P.R. \& Miflin, B.J. 1982. Differential protein accumulation during barley grain development. J. Exp. Botany 33: 717-728.

SALOMONSSON, L. \& LARSSON-RAZNIKIEWIICZ, M. 1985. Qualitative and quantitative studies of poroteins of wheat from different growing systems. Swedish J. Agric. Res. 15: 133-138.

Shewry, P., Tatham, A.S., Forde, J., Kreis, M. \& Miflin, B. 1986. The classification and nomenclature of wheat gluten proteins: A reassessment. J. Cer. Sci. 4: 97-106.
Sontag, T. \& SalovaAra, H. 1985. PAG electrophoregrams of wheat cultivars grown in Finland. J. Agric. Sci. Finl. 57: 271-277.

—, Salovaara, H. \& Payne, P.I. 1986. The high-molecularweight glutenin subunit compositions of wheat varieties bred in Finland. J. Agric. Sci. Finl. 58: 151-156.

Sozinov, A.A. \& PoperelyA, F.A. 1984. Blocks of gliadin components in wheat genetics, breeding and seed growing. Kulturpflanze 32: 165-170.

SvensSON, G. 1987. The importance of test baking in wheat breeding. Cereal Sci. and Technol. DCS. 23. Nordic. Cer. Cong. Copenhagen. p. 273-281.

- 1989. Breeding for improved baking quality. Sveriges Utsädesförenings Tidskrift 99: 117-120.

TANAKA, K. \& BUSHUK, W. 1972. Effect of protein content and wheat variety on solubility and electrophoretic properties of flour proteins. Cereal Chem. 49: 247-257.

UHLEN, A.K. 1990a. The composition of high molecular weight glutenin subunits in Norwegian wheats and their relation to bread-making quality. Nor. J. Agric. Sci. 4: 117.

- 1990b. Quantitative analysis of high molecular weight glutenin subunits in Norwegian wheats. Nor. J. Agric. Sci. 4: 19-25.

Waddington, S.R., CARTwright, P.M. \& WALl, P.C. 1983. A quantitative scale of spike initial and pistil development in barley and wheat. Ann. Bot. 51: 119-130.

Manuscript received July 1992

Jari Peltonen

University of Helsinki

Department of Plant Production

Viikki

SF-00710 Helsinki, Finland

Tuula Sontag-Strohm

University of Helsinki

Department of Food Technology

Viikki

SF-00710 Helsinki, Finland 


\title{
SELOSTUS
}

\section{Varastoproteiinien kehittyminen jyvän täyttymisjaksolla neljässä Skandinavisessa kevätvehnässä}

\author{
Jari Peltonen ja Tuula Sontag-Strohm \\ Helsingin yliopisto
}

Neljän sadonmuodostukseltaan ja leivontalaadultaan vaihtelevan kevätvehnän (Heta, Ruso, Reno, Kadett) satokomponentit, suurimolekyyliset gluteniinialayksiköt, gliadiinit sekă varastoproteiinien suhteelliset osuudet jyvän täyttymisjaksolla tutkittiin kenttäkokein kasvukausina 1989-90. Kokeet järjestettiin Helsingin yliopiston kasvintuotantotieteen laitoksella ja Hankkijan kasvinjalostuslaitoksella. Tulokset osoittivat, että aikaisuus on tärkeă valintakriteeri kevătvehnăn korkean leivontalaadun kannalta. Lyhyt jyvän täyttymisjakso on yhteydessä voimakkaaseen suurimole- kyylisten gluteniinien varastoitumiseen jyvän täyttymisjakson keskivaiheilla, mikă johti korkeaan valkuaispitoisuuteen ja valkuaisen laatuun mutta alhaiseen sadon määrään. Tulokset viittaavat siihen, että kevătvehnän sadon ja valkuaispitoisuuden välistä negatiivista suhdetta tulisi pyrkiả murtamaan valitsemalla aikaisin tuleentuvia, korkean jyvän valkuaispitoisuuden, korkean suurimolekyylisten gluteniinien måărăn ja suuren jyvălukumäärän tähkäăn tuottavia vehnälinjoja. 